\title{
Gin and other Drugs
}

\section{Karlie Moyle}

The stench of piss lingered in the cobblestone alleyway. It was daylight and the sign on the bar door said 'Closed'. Hell. The street was filled with polished boots, neckties and ambition. I looked at Remo. What are we doing here? He passed me a bottle in a brown paper bag. Then it suddenly occurred to me how we got here. It was that evil substance, cheap gin. I took a nice, long swig. It crept down my neck like second-rate razor blades. I was in Hell.

Now the battle to get home. It involved crossing a river. Remo said that he hoped no canoe was involved. I laughed with relief at that. I only became aware of the reek of liquor on my clothes when I boarded the tram. I became nervous and hoped to hell that the passengers would be too polite to draw attention to it. No one did. But I could tell they were only too aware of it. We may as well have been wearing signs that said 'fare evaders', I thought. We made it into town where Remo suggested we go to a bar to take the edge off for the next tram trip home. Maybe one drink.

The one gin and juice turned into a couple of golden ales and a couple of golden ales turned into a couple of whiskies and an argument with an old drunkard about Paul Kelly. I didn't care for Paul Kelly. We left the bar about six hours later to find the streets of Melbourne crammed with polished boots, neckties and the stench of battered ambition. We stumbled onto a tram making our way back home. Home, where the streets would be littered with lowlifes and drunks and deadbeats and junkies. I sighed with relief. 